\title{
Exploring Personal Political Brands of Iceland's Parliamentarians
}

\begin{abstract}
This paper focuses on an under-researched and under-developed typology of political branding and conceptualises politicians as personal political brands. Further, this study answers explicit calls for more research devoted to exploring the development of intended brand identity particularly from a brand creator perspective. Members of Parliament from the Republic of Iceland contextualises this study. This qualitative case-study approach reveals how personal political brands create, construct and communicate their identity. Personal political brand identities were established and managed via a clear brand mantra and offline-online communication tools, which in turn revealed a degree of alignment with their party-political brand. However, this paper also demonstrates the challenges of managing the identities of personal political brands in terms of authenticity and integration particularly with coalition partners. Our paper builds on the six-staged analytical process of personal branding and proposes the Personal Political Brand Identity Appraisal Framework as an operational tool to introspectively evaluate personal political brand identity. This framework can be used by political actors across different settings and contexts to assess personal political brands from multiple perspectives.
\end{abstract}

Key Words: Political Branding, Personal Branding, Brand Identity, Exploratory Research 


\section{Introduction}

In its simplest form, political marketing can be defined as the application of commercial marketing concepts, activities and frameworks to the political setting (Hughes and Dann 2009; Jain et al. 2018; Schofield and Reeves 2015). Political parties, politicians, prospective candidates, political institutions such as lobbyists and campaigners utilise commercial marketing techniques and tools to communicate, engage and build long-term relationships with citizens (Billard 2018; Harris and Lock 2010; Kornum and Muhlbacher 2013; Speed et al. 2015). Nevertheless, political marketing has evolved significantly as an international niche area of commercial marketing since the seminal work of Lock and Harris (1996). Indeed, political marketing represents a hybrid sub-discipline home to many specialised factions of study (Hughes and Dann 2009; Harris and Lock 2010; Marder et al. 2018). However, despite progress made within the political marketing area, more empirical understanding is needed as this will allow the sub-discipline to advance and continue to develop (Harris and Lock 2010; Hughes and Dann 2009; Jain et al. 2018; Needham and Smith 2015). Political marketing can only develop if it continues to apply new concepts or reapply advanced theories and frameworks (Nilsen 2016; Scammell 2015; Speed et al. 2015).

One well-documented faction of political marketing is the construct of political branding (Marder et al. 2018; Speed et al. 2015). However, political branding research remains underresearched (Harris and Lock 2010; Lock and Harris 1996; Moufahim et al. 2018; Nielsen 2016; Scammell 2015), particularly the internal orientation and intentional, desired positioning otherwise known as political brand identity. Existing studies that have tended to focus on the identity of 'party' political brands rather than that of politicians (French and Smith 2010; LeesMarshment 2001; Lees 2005; Nord and Stromback 2009; O’Cass 2001; Ormrod 2007; Pich and Dean 2015). Further, framing politicians as 'personal brands' allows us to explore the manifestations of intended identities, combined of personal characteristics such as personality traits, experiences feelings, beliefs and personal values (Jain et al. 2018; Johnson 2014; Rampersad 2008; Resnick et al. 2016), which up until now remained an under-developed research area. This study will not only address the explicit calls for further research in this area, but will also assist political entities to understand their desired identity and make adaptions if required (Baines and Harris 2011; Dann et al. 2007; Grimmer and Grube 2017; Ormrod 2011; Ormrod et al. 2007; Panigyrakis and Altinay 2017).

In this paper, we explore the creation and management of personal political brand identity particularly from the perspective of the brand's creators. Further, this will be achieved by bridging two streams of commercial branding theory such as personal branding and brand identity. More specifically, this study will investigate the creation and management of personal political brand identity by building on the six-staged personal brand auditing framework (Philbrick and Cleveland 2015) to examine the personal political brand identities of politicians from an internal brand-creator perspective. This will address the explicit calls for further research on the internal perspective of political brands, which in turn will extend an underdeveloped area of political branding (Billard 2018; Harris and Lock 2010; Needham and Smith 2015; Nielsen 2015; Nielsen 2016; O’Cass and Voola 2011; Panigyrakis and Altinay 2017; Scammell 2015; Serazio 2017; Speed et al. 2015). First, we discuss the background of political 
branding research. Then, discussions on internal brand identity, personal branding and personal political brand identity; further research with these concepts in the political context is then highlighted. The findings highlight applicability of the personal brand auditing framework to investigate personal brand identities. Further findings demonstrated that while both personal brands are authentic and clear, there is scope for refinement. This research concludes by identifying further research opportunities in the area of political branding and offers a revised framework to audit-assess personal political brand identity of politician brands.

\section{Political Brands}

Political brands are complicated entities (Billard 2018; Lees-Marshment 2009; Lock and Harris 1996; Phipps et al. 2010). Further, there are various manifestations of political brands such as political parties, party leaders, pressure groups, politicians, political campaigns and even nations can be conceptualised as brands (Guzman et al. 2015; Jain et al. 2018; Needham and Smith 2015; Peng and Hackley 2009; Smith 2009). Existing research in this specialised area highlights the diversity of political branding research (Bale 2008; Grimmer and Grube 2017; Needham and Smith 2015; Serazio 2017). For example, existing research has focused on party political brands (French and Smith 2010; Grimmer and Grube 2017; Milewicz and Milewicz 2014), human-politician brands (Billard 2018; Davies and Mian 2010; Guzman et al. 2015; Jain et al. 2018), cultural political branding (Smith and Speed 2011), development of new political brands (Panigyrakis and Altinay 2017; Busby and Cronshaw 2015; Nord and Stromback 2009), political brand identity (Pich et al. 2018), and political brand image (Guzman and Sierra 2009; Smith 2001). In addition, existing studies have investigated political brand equity (Phipps et al. 2010; Smith and Spotswood 2013), political brand personality (Guzman et al. 2015; Jain et al. 2018; Smith 2009), psychological profiling of politicians (de Landtsheer and de Vries 2015) and political brand positioning (Cwalina and Falkowski 2015; Smith 2005) across western (Billard 2018; Marland and Flanagan 2014) and eastern jurisdictions (Grube and Grimmer 2017; Jain et al. 2018). However, despite the advancements in political branding research, there are still many areas that continue to be under-researched and under-developed, which makes political branding a "critical and priority issue" for further research (Needham and Smith 2015; O'Cass and Voola 2011; Speed et al. 2015:130).

One area that seems under-developed is the notion of how to investigate political brands predominantly from the perspective of the brand's creator. More specifically, existing research devoted to an internal brand-creator perspective directs its attention to the political party or politician (Busby and Cronshaw 2015; Cwalina and Falkowski 2014; de Landtsheer and Vries 2015; Milewicz and Milewicz 2014; Smith and Spotswood 2013). However, very few studies with an internal focus manage to achieve a truly internal perspective. This paucity of research is supported by calls for further exploratory research particularly focused on different typologies of political brands (Billard 2018; Jain et al. 2018; Panigyrakis and Altinay 2017; Pich et al. 2018; Serazio 2017). Indeed, the majority of these studies practise content or discourse analysis of speeches and published articles rather than 'first-hand insight' from the personal standpoint of the political party or politician (Busby and Cronshaw 2015; Cwalina and Falkowski 2014; de Landtsheer and Vries 2015; Milewicz and Milewicz 2014; Smith and Spotswood 2013). It is unknown whether this is down to difficulties securing access to political 
stakeholders or their preferred method. However, Pich et al. (2018) is one exception. Pich et al. (2018) explored the creation, orientation and demise of a new political 'party' brand from the perspective of the party leader. Their study found new party brands face many challenges particularly barriers from the media and existing political system and difficulties with managing and a national-local campaign. In addition, Pich et al. (2018) provided a first-hand account of how difficult it was to build a party brand particularly from self-funding, nonexistent ideology, policy and absence of a support base. Pich et al. (2018) concluded future political branding research should devote attention to the exploration of the design and management of other typologies of political brands such as politician brands and investigate the relationship with the 'party' political brand from an internal brand-creator perspective. Therefore, the exploration of the development and management of politician political brands from an internal brand-creator standpoint will not only provide deep insight and first-hand accounts but also extend this under-developed area of political branding (Billard 2018; Jain et al. 2018; Needham and Smith 2015; O'Cass and Voola 2011; Panigyrakis and Altinay 2017; Pich et al. 2018; Scammell 2015; Serazio 2017; Speed et al. 2015). However, in order to investigate politician political brands from an internal perspective the concept of brand identity will serve as an appropriate theoretical lens to frame the exploration.

\section{Political Brand Identity}

Brand identity can be conceptualised as the desired perceptions and associations created and communicated by the brand's internal creators and conveys what the brand stands for (Aaker and Joachimsthale 2002; Aqeel et al. 2017; de Chernatony 2007). Further, brand identity signifies an organisation's current and envisaged reality (Baumgarth 2018; Nandan 2005). Similarly, Bosch et al. (2006) proposed brand identity as the preferred associations and aspired values developed by a brand's creator and focuses on the "central ideas of a brand and how the brand communicates these ideas to stakeholders" (de Chernatony 2007:45). In addition, brand identity is all about vision, values and aspiration (Dahlen et al. 2010; Gylling and Lindberg-repo 2006; Ronzoni et al. 2018). Indeed, brand identity continues to gain "worldwide recognition" and acceptance in academia and industry (Kapferer 2008:171). Thus, brand identity is an internally created manifestation created and developed through physical properties such as communication tools and relationships and intangible properties such as actual and desired positioning, core beliefs and a brand's heritage. Brand identity has to be consistent and durable yet adaptable and ready to change depending on changes/crises in the internal and external environment (Alsem and Kostelijk 2008; Aqeel et al. 2017; Dahlen et al. 2010; Gylling and Lindberg-repo 2006). Therefore, brand identity is a key approach to strengthening and building a brand (Aaker 1996).

Nevertheless, "the principle task of uncovering identity is exploration" (Bronn et al. 2006:889). This will reveal what the brand stands for and uncovers the brand's aspirations but will also highlight any inconsistencies or challenges with the brand (Baumgarth 2018; Nandan 2005). Once the current-envisaged identity is understood, the brand's creator can adapt or refine the tangible and intangible touchpoints to address any inconsistencies or misalignment. However, there is a paucity of research on the exploration of political brand identity. The few studies that have focused on the internal orientation or identity of political brands [identity] have tended to 
focus on three broad areas. This includes the investigation of 'party' political brand identity, the business-orientation of 'party' brands or the applicability of brand identity-personalityequity models to the context of 'party' brands (French and Smith 2010; Grimmer and Grube 2017; Jain et al. 2018; Lees-Marshment 2001; Lees 2005; Nord and Stromback 2009; O'Cass 2001; Ormrod 2007; Pich and Dean 2015; Pich et al. 2018). This suggests there is very little research dedicated to the exploration of the identity of politician political brands particularly from the standpoint of the brand-creator. This would address the explicit calls for further research on the internal perspective of political brands (Billard 2018; Jain et al. 2018; Needham and Smith 2015; O'Cass and Voola 2011; Pich et al. 2018; Scammell 2015; Serazio 2017; Speed et al. 2015). This in turn would allow the discipline of political branding to advance as a specialised area of study (Harris and Lock 2010; Needham and Smith 2015; Nielsen 2015; Nielsen 2016; O'Cass and Voola 2011; Panigyrakis and Altinay 2017; Scammell 2015). However, how can we conceptualise the political brands of politicians and investigate their internal identity? Perhaps the theory of personal branding will help conceptualise politician political brands and highlight how we can examine or audit political brands.

\section{Personal Political Brand Identity}

In its simplest form, personal branding can be defined as the application of traditional branding concepts and frameworks to people (Chen 2013). Indeed, personal branding has been described as a 'process by which an individual actively tries to manage others' impressions of their skills, abilities and experiences' (Johnson 2014:2). In addition, personal branding is strategically employed by celebrities, sports personalities, journalists, business leaders, entrepreneurs, students and politicians as a strategy to project an authentic character, which is distinct from rivals and competitors (Chen 2013; Cortsen 2013; Gehl 2011; Lair et al. 2005; Ottovordemgentschenfelde 2017). Further, personal brands are manifestations of intended identities, perceptions combining personal characteristics such as personality traits, experiences, feelings, beliefs and personal values (Johnson 2014; Rampersad 2008; Resnick et al. 2016).

Personal brands are structured around tangible dimensions such as physical appearance, style, online and offline communications and actions-activities, and also intangible dimensions such as lived experiences, life-stories, values, charisma and apparent authenticity and authority (Chen 2013; Gehl 2011; Green 2016). Personal branding can trace its origins to self-identity research developed in the 1940s as a method to express individuality (Philbrick and Cleveland 2015). The practice of personal branding was then 'popularised' by Peters (1997) in his seminal study entitled 'The Brand Called You' which argued the strategy could and should be utilised by everyone beyond the world of business, entertainment and politics (Chen 2013; Lair et al. 2005; Marland 2016; Philbrick and Cleveland 2015). Indeed, Shepherd (2005) argued that personal branding is an inside-out process and brands should routinely take stock or audit the current and intended identity. The importance of conducting a personal brand audit or assessment is similar to the work of Philbrick and Cleveland (2015) who outline a six-stage approach to assessing personal brands. This has been developed to consider a 'personal political brand' as outlined in figure 1. 


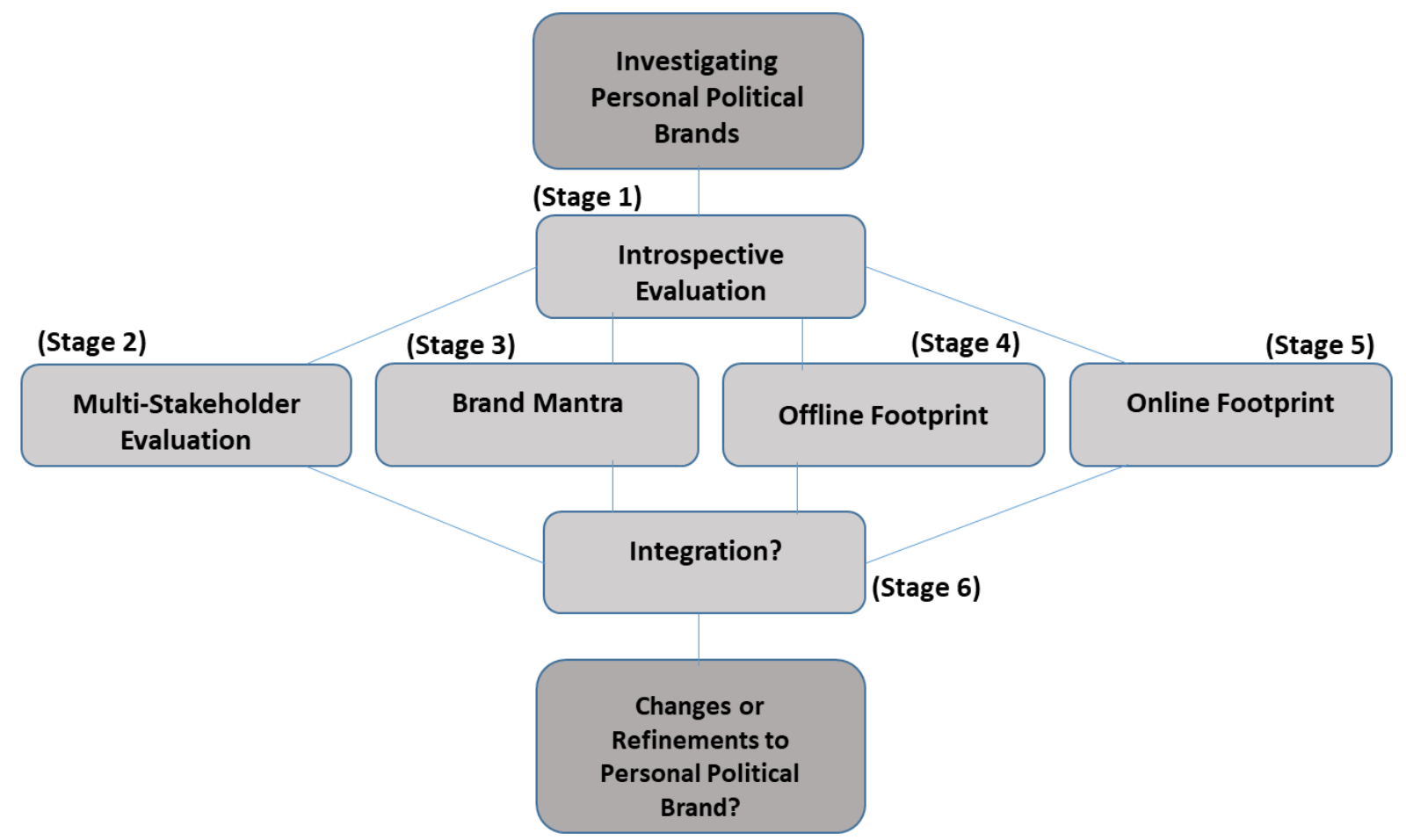

Figure 1: Six Stages of Evaluating Personal Political Brands developed from Philbrick and

Cleveland (2015)

Stage one focuses on the first stage of the auditing process [introspective evaluation] whereby the personal political brand attempts to understand their current and desired position and ideology. Once this has been uncovered, the second stage where individuals take time to assess the current understanding of their personal brand from the perspective of multiple stakeholders. Stage three involves ascertaining whether the personal political brand has a clear, unique mantra that signifies a consistent vision. If not, this can be created as part of the brand's development. Stage four focuses on investigating the current and desired physical or offline footprint [communicative tools] to develop an intended identity. Stage five focuses on exploring the current digital presence or footprint used by the personal political brand. Finally, stage six involves assessing whether all the stages are integrated or aligned. If not, the politician can develop a strategic plan to refine their brand and ensure closer alignment and consistency with all communicative touch-points and projecting the updated personal brand to the target market (Philbrick and Cleveland 2015). Subsequently, a common theme seems to be present across the personal branding literature namely the significance of conducting periodic audits to assess a personal brand's current identity from an internal standpoint, which will help refine or reconstruct an envisaged identity (Brooks and Anumuda 2016; Philbrick and Cleveland 2015; Shepherd 2005). In addition, the existing literature argues that it is vital for personal brands to monitor their target market, competitors and communicative tactics in order to build long-term relationships with multiple audiences (Shepherd 2005; Ward and Yates 2013).

Nevertheless, personal branding has been extended to various disciplines and subject areas such as self-help management, employability, marketing-communications, entrepreneurship, health sector (Gehl 2011; Green 2016; Harris and Rae 2011; Johnson 2014; Lair et al. 2005; 
Philbrick and Cleveland 2015; Resnick et al. 2016; Shepherd 2005; Thompson-Whiteside et al. 2017). However, the strategy is challenging and often misunderstood due to the various interpretations of this subject area (Chen 2013; Thompson-Whiteside et al. 2017). For example, personal branding [and personal brands] are often interchangeably referred to as 'selfbranding', 'self-marketing', 'self-promotion', 'human-branding', 'self-presentation', 'narrative identity', 'image-management and 'impression management' (Brooks and Anumuda 2016; Chen 2013; Marland 2016; Marwick and Boyd 2010; Resnick et al. 2016; Shepherd 2005; Speed et al. 2015). Therefore, personal branding remains a contested strategy across academia, thus it is not surprising that there is no universal definition ascribed to personal brands (Marland 2016). Subsequently, this study will build on the work of Philbrick and Cleveland (2015) and utilise the six-staged framework [figure 1] to assess and audit the personal political brand identities of politicians from an internal brand-creator perspective. The aim of this study is to investigate the personal brand identities of two Icelandic Members of Parliament from an internal perspective. The justification for focusing on the context of Iceland will be discussed in the next section. Nevertheless, the objectives are to explore the personal brand identity of members of the Icelandic Parliament from an internal perspective; compare the personal brand identities of Iceland's political brands and to assess the usability of the Personal brand auditing framework as a tool to understand and manage personal political brands. The first-hand accounts will provide deep insight into how internal brand identity of personal political brands is created and managed, which in turn will address the explicit calls for further research on the internal perspective of political brands (Harris and Lock 2010; Needham and Smith 2015; Nielsen 2015; Nielsen 2016; O'Cass and Voola 2011; Scammell 2015). This will also extend an under-developed area of political branding (Needham and Smith 2015; O’Cass and Voola 2011; Scammell 2015; Speed et al. 2015).

\section{Methodology}

This study adopted a qualitative case-study approach to investigate how two politicians create, construct and communicate their political personal brand. Qualitative research was chosen as it aims to build an extensive picture of respondents' background, their feelings and experiences to address the research objectives (Schutt 2004; Warren and Karner 2005). In addition, qualitative research can also be helpful for new or under-researched areas of study (Davies and Chun 2002). A case study approach can be seen as "an empirical inquiry that investigates a contemporary phenomenon in depth and within its real-life context, especially when the boundaries between phenomenon and context are not clearly evident" (Yin 2009: 18). Indeed, a case study approach is recognised for its capability to reflect a single or complex research problem and is particularly beneficial when addressing how and why questions (Baxter and Jack, 2008). Further, case studies can focus on an individual, organisation, campaign or even location (Lincoln and Guba 1985; Welch et al. 2011; Yin 2018). In order to contextualise this study, the Republic of Iceland was selected to frame the discussion, which in turn represented an under-researched setting worthy of further research (Nord and Stromback 2009; O'Cass 2001; Ormrod 2007; Pich et al. 2018). 
Icelandic politics has been rocked by a succession of financial scandals (Henley, 2018), which resulted in Icelandic General Elections contested in 2013, 2016 and 2017 instead of every four years. The sporadic number of General Elections in a short space of time changed the character of the Icelandic Parliament with the appointment of newly elected parliamentarians representing half of the number of seats within parliament (Magnúsdóttir, 2017). Therefore, this paper adopted a purposive sampling approach. Purposive sampling can considered an appropriate sampling technique as this paper had a specific purpose to explore how internal brand identity of personal political brands is created and managed from an internal brandcreator perspective (Alston and Bowles 2007; Zikmund 2003). Iceland is divided into six parliamentary constituencies. Initially, six prospective participants, one from each constituency were emailed via the online parliamentary website with a view to take part in the study. This resulted in two declines, two non-responses and two acceptances. Therefore, as case studies can focus can on individuals (Lincoln and Guba 1985; Welch et al. 2011; Yin 2018), two Members of the Icelandic Parliament served as the sample of this study. A profile of each case is set out in table 1 .

Table 1: Parliamentary information on the two cases

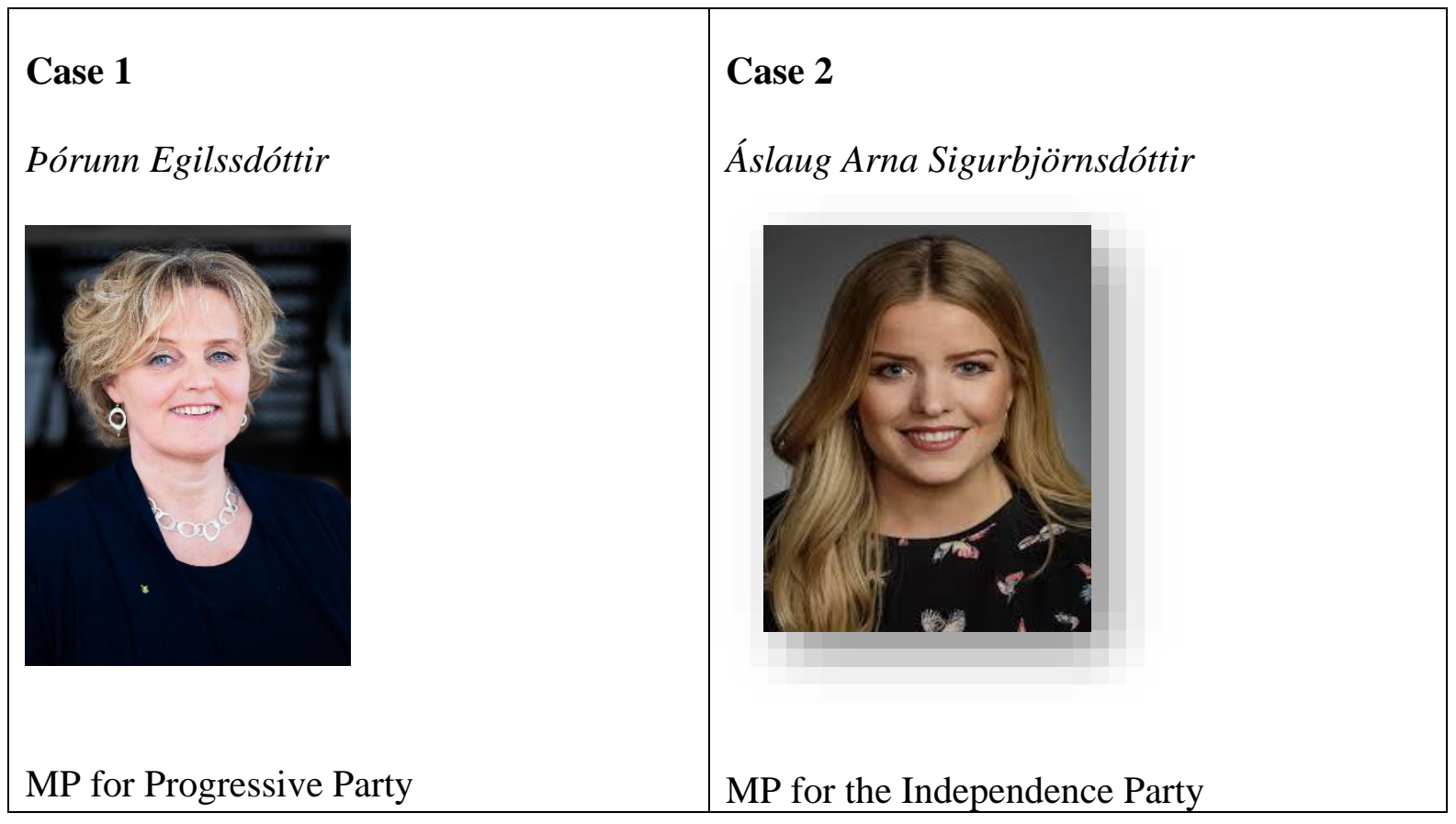


Member of Althingi for the Northeast

Constituency since 2013.

In coalition government with the Independence party and Left-Green party since 2017

Deputy Speaker of Althingi since 2015.

Chairman of the parliamentary group of the Progressive Party since 2016 and 2015.

Member of the Constitutional and Supervisory Committee since 2017.

Deputy Chairman of the Icelandic delegation to the West Nordic Council since 2017.
Member of Althingi for the Reykjavík North Constituency since 2016

In coalition government with the Progressive party and Left-Green party since 2017

Deputy Chairman of the parliamentary group of the Independence Party since 2017

Chairman of the Foreign Affairs Committee since 2017.

Chairman of the Icelandic delegation to the Inter-Parliamentary Union (IPU) since 2017.

Member of the EU-Iceland joint

Parliamentary Committee since 2018

Source: (Althingi, 2018 a, b).

The two politicians were both relatively new to the Icelandic Parliament. For example, case one was elected in 2013 for the Progressive Party, a centre-right and agrarian party founded in 1916 and currently part of the ruling coalition government (Bergqvist 1999; Wolfram 2017). Case two was elected in 2016 for the Independence Party, a liberal-conservative Eurosceptic party founded in 1929, currently the largest party and leading coalition partner in the Icelandic Parliament (Joakim 2006; Wolfram 2017). Therefore, both cases continue to develop their brands in a dynamic, complex market and these first-hand accounts would provide deep insight into the creation and management of intentional identity. This in turn support calls for further research to investigate political brands from an internal perspective (Harris and Lock 2010; Needham and Smith 2015; Nielsen 2015; Nielsen 2016).

This study adopted in-depth elite interviews consistent with an interpretive inductive approach (Alston and Bowles 2007; Zikmund 2003) to explore each political brand identity. Elite interviews can be characterised as comprehensive discussions with a small number of experts or participants with specialist knowledge designed to capture insightful perceptions (Beamer 2002; Lillieker 2003). Interviews were conducted face-to-face in August 2018 and lasted 60 to 120 minutes. In-depth, elite interviews are often seen as a "special conversation" (Rubin and Rubin 1995:6) where the role of the interviewer is to build a picture of the feelings, attitudes and views of the interviewee without leading the respondent and creating any bias (Silverman, 2013). The interview guide was developed by the researchers after reviewing the literature on political and personal branding (Gillham 2005). However, the interview guide represented a broad structure to facilitate the discussion and encourage as natural discussion as possible rather than serve as a strict protocol, which could stifle the "special conversation" (Foddy 2001; 
Gillham 2005; Rubin and Rubin 1995:6). A copy of the interview guide can be seen in appendix 1. The in-depth elite interviews were enhanced with a number of data collection methods including non-participant observations such as the review of public websites containing news updates, manifestoes, personal background information and policy related information. In addition, public social media sites including Twitter, Instagram and Facebook were analysed to generate deep insight and a greater understanding of each case (Foddy 2001; Saunders et al. 2012). This in turn allowed methodological triangulation, which helped strengthen the research findings by comparing and contrasting emerging themes and revealing a holistic view of each political brand identity (Easterby-Smith, Farmer et al. 2006; Saunders et al. 2012; Thorpe, and Jackson 2015).

The elite interviews were conducted in Icelandic and transcribed and translated into English by the researchers. Transcription was completed within one week of the interviews. A draft copy of the article was sent to the participants in a process of participant validation or member checking to give greater rigour to the research and reduce bias (Warren and Karner 2005). This study adopted a two-staged thematic analytical process to analyse the transcripts and secondary resources-material (Butler-Kisber 2010). Thematic analysis involves the practice of identifying common themes and unique codes from the findings in order to interpret and make sense of the phenomenon (Butler-Kisber 2010; Hofstede et al. 2007; Warren and Karner 2005). More specifically, Butler-Kisber (2010) proposed two distinct stages to manage the analytical process. The first 'coarse grain' stage began at the interview stage each interview was recorded, transcribed by the researcher and read and re-read in an iterative process (Braun and Clarke, 2006; Butler-Kisber 2010). Each interview was reviewed in isolation and initials codes were generated to review themes and patterns across the interviews and public material. More precisely, thematic analysis helped with encoding the findings by "categorizing or the comparing and contrasting of units and categories of the field texts to produce conceptual understandings of experiences and/or phenomena that are ultimately constructed into larger themes" (Butler-Kisber 2010: 47). The fine-grained stage was focused revisiting themes identified from the coarse-grained stage (Bird et al. 2009; Butler-Kisber 2010; Hofstede et al. 2007; Warren and Karner 2005). This introduced a process of constant comparison, which ensures the researcher constantly compares the phenomena and the themes and subthemes across the two cases (Glaser, 2014). The final part of the fine stage analysis considers the secondary data and continues the process of methodological triangulation reviewing social media sites (Saunders et al. 2012). This systematic process revealed several themes and subthemes such as identity creation, communication tools and challenges of brand management. The following section will present and discuss the uncovered findings.

\section{Findings}

This study aims to explore the creation and management of personal political brand identity from a brand creator perspective. The themes which arrived from the thematic analysis were identified as identity creation, communication tools and challenges of brand management as discussed in the next section. 


\section{Identity creation}

When addressing these politicians' identity creation, we explored their political values, their ideology and key issues as well as their personality and personal characteristics as these are all dimensions of a personal brand (Johnson, 2014). Both politicians had a clear, unique brand that signified their vision and values, as identified by the brand identity literature (Bosch et al., 2006; Dahlen et al. 2010). It was found that case one's values, key issues and ideology were intertwined to give her personal brand credibility. Identity was grounded on personal issues such as a personal passion for representing local rural constituents and a decentralised apporach, yet infastructure for the whole island. For example, case one on three occations submitted a bill to Parliament which addresses the use of land owned by the government, especally land rented by farmers [she put it forward for the fourth time in September 2018]. This bill has three main objectives; to ensure the possibility of government land being used for farming and that people are given the opportunity to start farming; to define which geographic areas should be rented out and which sold and finally to make sure that nature and tourist consideration are taken into account when all above is addressed (Althingi, 2018c). Another key issue for case one is to keep the whole island habitable. In order do so, the island needs to be connected by optical fibre broadband and transportation needs to be realiable and affordable. For example "transportation will have to work, it's the foundation [as] the country is large and expansive" (Interview Case 1). Air travel is not an option for people living farthest away from the services in Reykjavik as it is too expensive.

\section{"When I started in parliament then I didn't have a mobile connection where I live [in Vopnafjordur], we had a special solution, so we could watch TV and the internet connection was bad. Nobody believed me when I told them that I would be at home over the weekend, but you would need to ring my landline" (Interview Case 1).}

When the whole island is all connected then the aim is to start adverting jobs, so you can work from anywhere within Iceland. This is a Progressive party policy and is something the party has been working towards for years. Similarly, case two values reflect her party values and her wish to restrict government intervention within the economy. For example, it was revealed that "we have so many creative, hard-working people in this country and we trust them to do what's best. We often see that Icelanders can do extraordinary things, not just in football" (Interview Case 2). She believes the state should focus on providing excellent healthcare and education, take care of transportation, roads, benefit system, the elderly, court of law and police. Her key issues reflect topics important to young people of her generation; education and affordable housing and those are the policies she is working on.

Both politicians claim to portray an authentic personality which consists of positivity and diligence. Both say they are positive and hard-working. Case 2 says she is positive and organised, expressing she wants to have plenty to do. Case 1 says she is positive, realistic and firm. When parliament is operating case 2 is working most days until $7 \mathrm{pm}$. "You need to prepare bills you need to address, read for your work in committees and meet people. Over the weekend you can be on TV or radio programme, or in meetings around the country" (Interview Case 2). Case 1 says this is not a family friendly job, you will need a supportive partner, 
especially if you have some children. She says that everything in the parliament pushes people to live in Reykjavik. However, her view is that it is important to connect with her society and this connection might be lost if she would live all year around in Reykjavik.

Both politicians make sure they were accessible and as a part of this answered all emails and requests from the public. Case 1 says: "I can't always solve problems or do anything, but it is necessary to show interest in people "(Interview Case 1). Case 2 says she tries to answer all her correspondences. "I try to answer them all, can be difficult but I try to be accessible and answer it all, from Twitter, Instagram and Facebook or my email "(Interview Case 2).

From above it appears that participants strive to be seen as authentic personalities and strong personal brands. Nevertheless, we can only reveal if cases were deemed authentic if we investigate this from an external-voter perspective. This is, however, beyond the scope of this study.

\section{Communications Tools}

Brand identity is created and developed through communications and relationship (Gylling and Linderbergrepo, 2006, Shepherd, 2005). In this study the politicians reflected on how they communicated with the people within their constituency both offline and online. Case 1 defines her target market quite broadly as "hard working people with both feet on the ground, which understands their society" (Interview Case 1). Case 2 identities 3 different target markets. She says:

"It is young females, who believe in right-wing politics. They have not found individuals to follow. This is my biggest target market. Another target market is young males and then I have an older market, to which I try to communicate "(Interview Case 2).

Indeed, both politicians recognise the importance of communicating their personal brand to voters and both tailor their message to their target market. This is illustrated via both online and offline touchpoints, which create a consistent footprint.

\section{Offline footprint}

Case 1 relies more on offline channels than case 2. Her constituency is geographically large, but this does not stop her from visiting each town/village at least twice a year, during her constituency weeks:

"I do more than this. I think I didn't manage to spend a whole weekend here at home over winter. My trip home for Easter was the $6^{\text {th }}$ visit I made since Christmas and New Year. One weekend Iflew to Egilsstaðir on Saturday and had a meeting there, came here to Vopnafjordur and had a meeting here on Sunday, drove to Seydisfjordur on the Sunday to have a meeting there before driving back to Egilsstadir to fly back to Reykjavik. I use the trips [back home] for meetings" (Interview Case 1). 
In addition, she mentions that people will ring her up if they need her help. Case 2 writes for the largest subscription newspaper in Iceland which has $17.4 \%$ reach in the Reykjavik area for people 18-49 years old (Gallup 2018), but she is aware that her target market is not necessarily reading the paper, but her party members are so it keeps her name and her issues in the spotlight. She does not attend meetings apart from those she does with her party members as young people do not turn up to meetings.

\section{Online footprint}

Both politicians communicate through online media. Firstly, all parliamentary speeches are available on the parliamentary site, Althingi.is. Case 1 uses Facebook and though her profile is not public her posts are. Her posts show her life as an MP, farmer, wife, mother. However, equally as an MP she addresses the key concerns of her electorate in a timely manner. (Facebook case 1). However, she does not use any other online media.

Figure 2: Case 1 - Parliamentary Page - (althingi, 2018a)

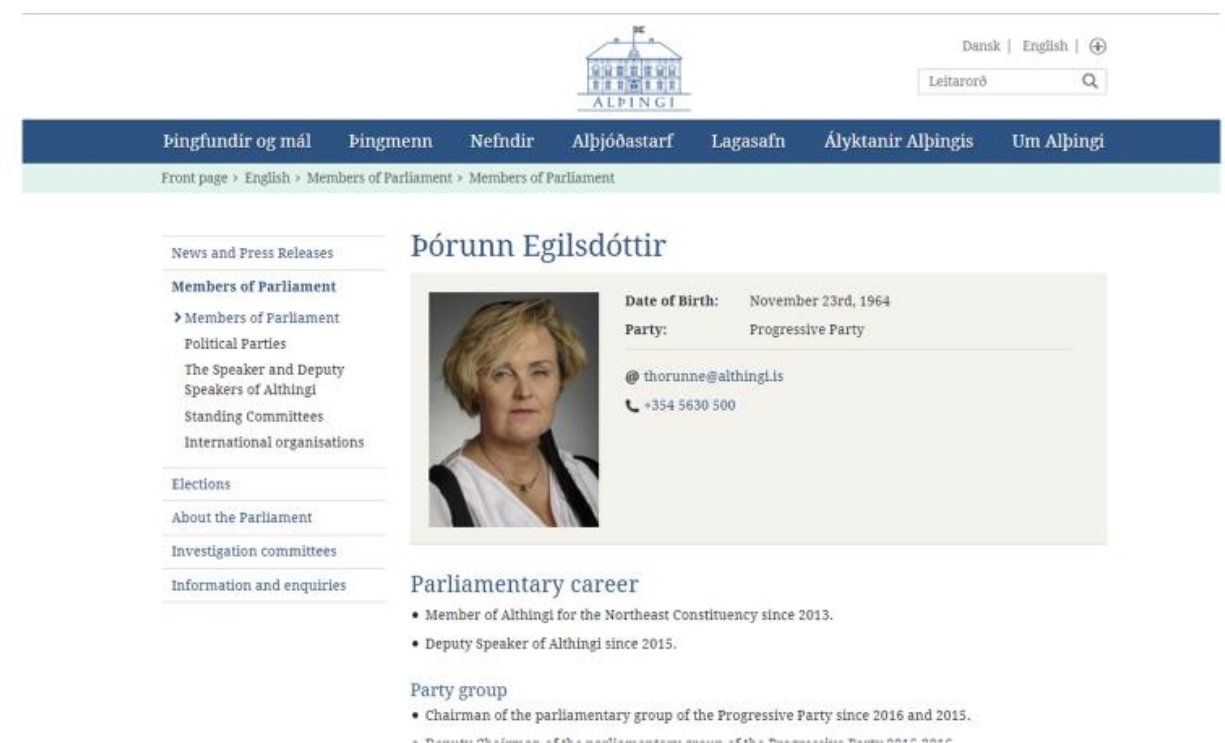


Case 2 knows how to use the online media and does so in a strategic manner. Her online footprint is stronger than Case 1's but this could be explained by her target market being young people, who spend time on social media and are interested in following a politician like themselves. Case 2 has thought about how to communicate her identity and how to make the most use of each media. "I think it is important to try new ways to do so, not because I was trying to distinguish myselffrom those I was competing with but also because I'm younger than most candidates" (Interview Case 2). She has public Instagram, Facebook and Twitter and uses all differently. She says she reaches people below 40 years on Twitter and Instagram. She can only write short messages on Twitter and most of her Twitter posts are on politics and current affairs (Twitter Case 2). She posts more about her personal life on Instagram such as holiday pictures and pictures of her with family and friends (Instagram Case 2) but puts all her published material on Facebook. Figure 3 shows the Facebook, Instagram and Twitter pages for case 2 .

Figure 3: Case 2 - Social Media Pages (2018) 


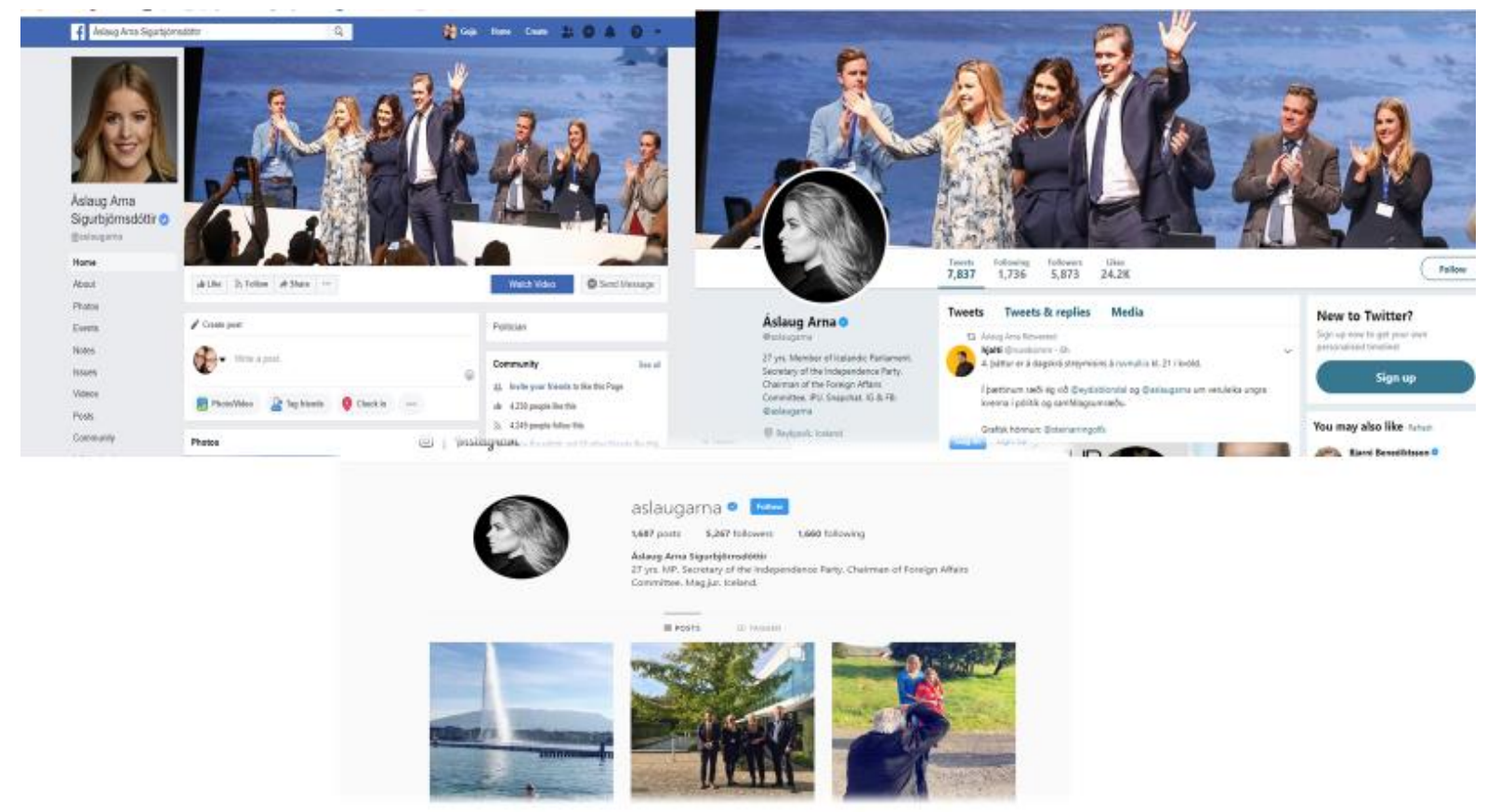

Both online and offline communications are consistent with the politicians' brand identity and their values. The findings show clearly the opportunities which social media sites gives to politicians, it's easier to promote themselves and show different side to their personality. Case 2 has stratically analysed how to distinguish herself from other candidates and how she can use the different online platforms to communicate her identity, values and policies. These findings also show that there might be an opportunity for case 1 write more about her views, values and policies, either on social media or in the newspapers to reach a wider audience.

\section{Challenges of brand management}

The integration stage on the personal brand auditing framework assess whether all the stages are integrated or aligned as communicating a clear, coherent personal brand identity which is vital for success (Pich and Dean, 2015). While the politicians seemed to have developed and communicated strong personal brands, several threats were identified. As both were in coalition government there was a threat of losing their identity and even losing the party identity. Both politicians identified this as a challenge but were aware of this situation as coalition governments are the norm in Icelandic politics. Both politicians identified that working in a coalition government with three different parties as being a challenge even though they also said that it had its benefits as more people would support the government. The main challenge is however to come to agreement and to reach a compromise. Another challenge is to maintain a party identity.

"It's easy to lose it when you are part of a coalition government, especially when the parties are different. [...] We regularly remind 
ourselves why we were elected and how we can achieve our goals with the ministries we have" (Interview Case 2).

Case 1 said the party was currently doing well at maintaing their identity but this is the second time she has participated in a coalition government. In terms of brand management, both politicians had party activists within their party which they could get feedback from about their brand and brand development. These people offered internal support to help the politicians manage and integrate their brands. Not only did these people give feedback on policies and issues but also on what to wear. Both politicians had thought about adjusting their personal brand. For example case 2 had to think carefully about what she shares with people and how she does this through her social media channels. She has modified her personal brand to show more sides to herself, trying to become more than just a potential candidate to become a fully formed individual who has a place in politics. "They say I'm just a kid in politics and that I'm undeservedly in parliament. I need to show this is not the case and that I have more to offer than people think "(Interview Case 2). She says she communicates her personal brand through social media, but she has to be careful: "I need to hold onto being 27-year-old but at the same time behave as a 40-year-old. I can't party like my peers can do, I can't show everything." (Interview Case 2). She also says she has to work harder the older MPs as she is "under the microscope" [...] "you can't really be yourself because people will misunderstand you or twist everything. I put some joke on [social media site] and it becomes a front-page news in DV [newspaper]." (Interview Case 2). Case 2 is likely to have to carefully manage her brand in the future until people accept her as a fully formed MP.

Case 1 says people have all sorts of opinions about her: "what you should wear, how you look, if you are getting smaller or bigger" (Interview Case 1). She has also been told she doesn't speak enough during parliamentary meetings. However, case 1 has taken a different approach and not adjusted her personal brand. She worries she will lose her credibility if she starts changing her personal brand, which might be the case as she is an established individual, but some refinement might be done to introduce her to new voters and get her policies across.

These findings show that these politicians' identities are not static, they are dynamic and will continue to evolve and change as politicians get more feedback from their environment. It is likely that there is always going to be tensions or concerns about managing multiple identities to different audiences as it can mean losing your own authentic identity.

\section{Application}

This study has applied the six-staged framework (Philbrick and Cleveland, 2015) to assess and audit the personal politician brand identities of Icelandic MPs. However, as the research only addressed the MPs internal perspective the multi-stakeholder evaluation stage has been omitted (Figure 4 the introspective evaluation of personal political brands). However, overall the model suggests a refinement and considers the key elements that should be addressed in creating a robust personal political brand identity. 


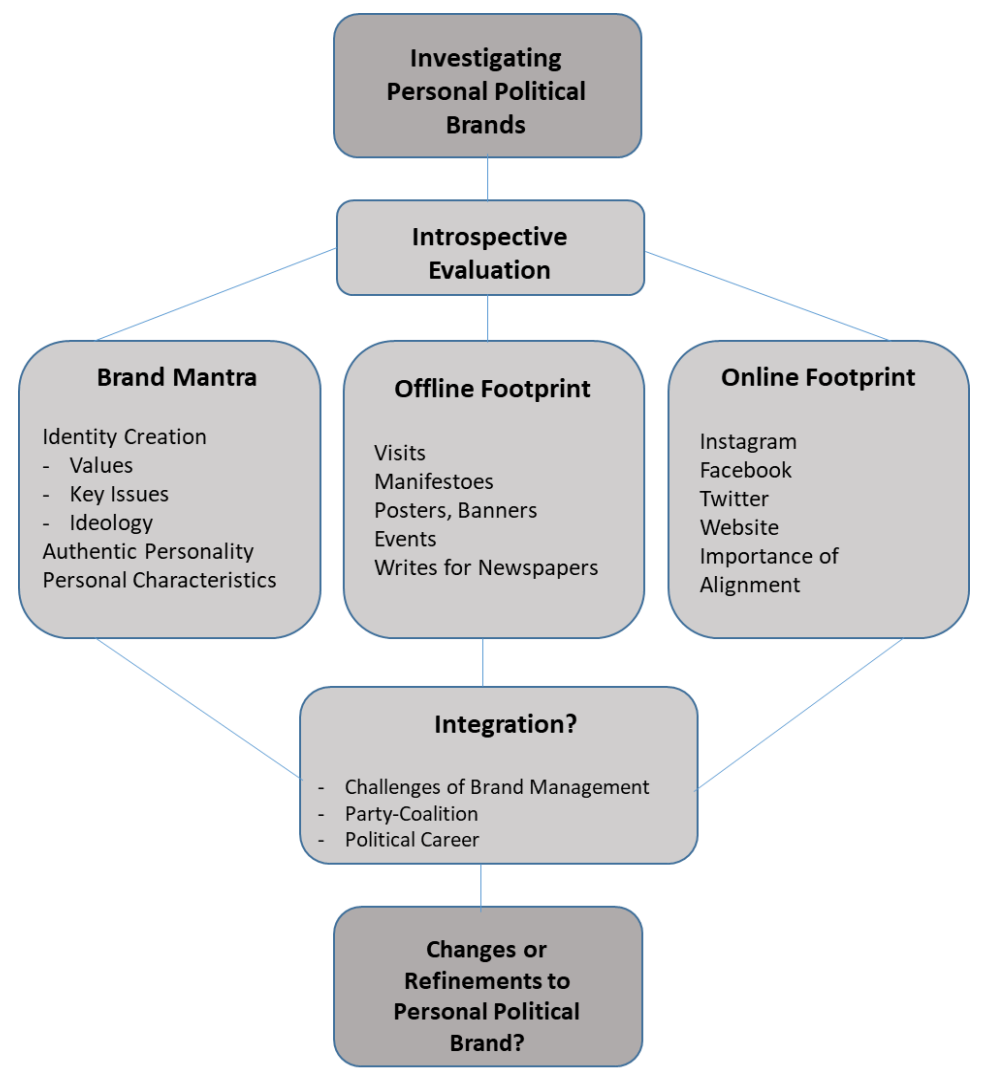

Figure 4 - The Introspective Evaluation Framework for Personal Political Brands developed from Philbrick and Cleveland (2015)

The two politicians demonstrate two very different personal brands, which seem to be tailored to their constituencies. Moreover, both define a strong brand mantra whilst faced with different challenges. Case 1's personal brand is deeply rooted in her life as a farmer, living in a rural part of the island while Case 2's personal brand is young and fresh, she focuses on issues that are important to young people like herself in a process of introspective evaluation. Case 2, as a young politician, is likely to continue to refine, to develop and adjust her personal brand to better fit her target market. While she says that people voted for her, not a 40-year-old woman, she will need to maintain a respected image to suit an MP and on social media she will continue to have challenges with what to communicates and what not to include considering her offline and online footprint. This will be her challenge in the coming years. However, she has reflected more about how to create and maintain her personal brand than case 1. Case 1 has a clear personal brand but needs to make sure it is still current for her target market and she is not taking advantage of all the different ways she can communicate her policies or who she is. Her view on society and the future of the island is relevant to people but it not necessarily communicated clearly or through the relevant media but investing more time and effort writing either in newspapers or on social media might help communicate the brand more clearly.

\section{Discussion}

As Bronn et al. (2006:889) argued, "the principle task of uncovering identity is exploration". Indeed, this study explored the personal brand identities of two Icelandic Members of 
Parliament from an internal perspective. This was achieved by expanding the work of Philbrick and Cleveland (2015) and utilised the six-staged framework [figure 1] as a broad framework to uncover personal political brand identity and assess its usability as a tool to understand and manage personal political brands. For example, this study highlighted that while both politicians communicated clear and consistent personal brands they had thought about modifying it make it fit better with people's perceptions of them. Further, this study uncovered the preferred associations and aspired values developed by the brand's creator, which in turn highlighted the "central ideas of a brand and how the brand communicates these ideas to stakeholders" (Bosch et al. 2006; de Chernatony 2007:45). For instance, both politicians' values and ideoloigies seems to be consistent with their lifevalues. Indeed, these internally created manifestations were created and developed through the use of physical online and offline communication tools such as Twitter, Facebook and Instagram yet also with traditional tools such as posters, manifestos and attending events (Dahlen et al. 2010; Gylling and Lindberg-repo 2006; Pich et al. 2018). In addition, it was found that relationships with various stakeholders such as constituents, businesses and other politicians also helped manage the personal political brand. The personal political brands also utilised intangible properties such as expressing current and desired positioning, demonstrating core beliefs and the importance of their heritage to develop their intentional identity. Therefore, our findings concur with the notion that brand identity is all about vision, values and aspiration (Dahlen et al. 2010; Gylling and Lindberg-repo 2006; Pich et al. 2018).

These first-hand accounts revealed deep insight into how internal brand identity of personal political brands was created and developed, which in turn addresses the explicit calls for further research on the internal perspective of political brands (Harris and Lock 2010; Needham and Smith 2015; Nielsen 2015; Nielsen 2016; O’Cass and Voola 2011; Scammell 2015). This also shines some light onto the identities of different typologies of political brands such as politicians, which up until now remains under-developed compared to research on 'party' political brands (French and Smith 2010; Lees-Marshment 2001; Lees 2005; Nord and Stromback 2009; O'Cass 2001; Ormrod 2007; Pich et al. 2018; Pich and Dean 2015). Therefore, this research demonstrates the exploration, development and management of politician political brand from an internal brand-creator standpoint supported by the six-staged personal branding framework. This addresses the explicit calls for further research, which in turn enables the discipline of political branding to advance as a specialised area of study (Harris and Lock 2010; Needham and Smith 2015; Nielsen 2015; Nielsen 2016; O'Cass and Voola 2011; Scammell 2015).

\section{The Personal Political Brand Identity Appraisal Framework}

This study applied four of the six stages [brand mantra, offline footprint, online footprint and integration] to investigate personal political brand identity outlined in figure 1. For example, the brand mantra [stage three], offline footprint [stage four], online footprint [stage five] and integration [stage 6] were clearly applicably to assessing the intentional identity. The brand mantra included themes related to identity creation such as values, key personal issues and 
ideology but also personal characteristics of the individual and the importance of an authentic personality. The Offline and online footprint captured the tools, techniques and activities used to communicate and project a desired identity. Whereas integration revealed the challenges of creating and managing personal political brand identity, the relationships and alignment with the political party and coalition partners but also long-term aspiration of the individual. However, this study also revealed that two of the six stages [introspective evaluation and multistakeholder evaluation] were problematic when attempting to evaluate the personal political brands. For example, stage one [introspective evaluation], seemed to be part of the complete evaluative process of all six-stages rather than be considered a standalone stage. Further, by investigating the brand mantra, online and offline footprints and integration would in effect represent an introspective evaluation. Therefore, if stage one was evaluated as a standalone element then that would be merely a replication of the following stages and not reveal new insight. In addition, stage two [multi-stakeholder evaluation] was also difficult in this investigation as this research aimed to explore the personal political brand identity from the brand's creator rather than including additional stakeholders such constituents, supporters, competitors and party members. This in turn will reveal additional insight into integration, alignment and authenticity (Chen 2013; Gehl 2011; Green 2016).

As a result, this study presents a revised framework [figure 5] designed to evaluate current and desired personal political brand identity from a multi-stakeholder perspective. The revised and renamed Personal Political Brand Identity Appraisal Framework builds on the work of Philbrick and Cleveland (2015) and reflect key themes identified as part of this study [figure 4]. In addition, the Personal Political Brand Identity Appraisal Framework is structured into three systematic phases outlined below. 


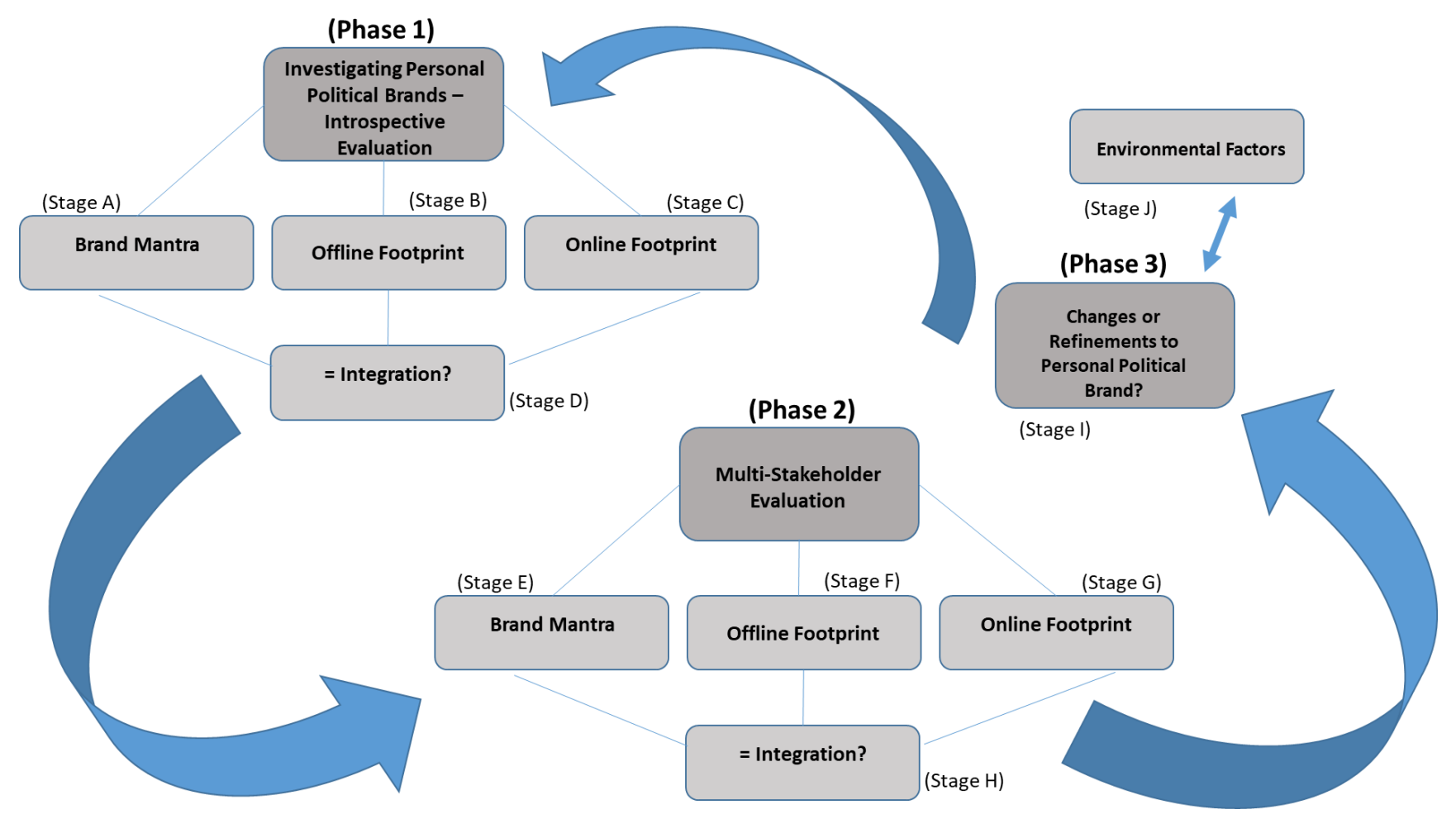

Figure 5: The Personal Political Brand Identity Appraisal Framework

Phase one would involve four stages exploring the current brand mantra [Stage A], offline footprint [Stage B], online footprint [Stage C], which in turn will reveal an up-to-date reflection of the personal political brand and assess its consistency [Stage D]. Once this introspective evaluation has been conducted, the appraisal would move to phase two and this would involve repeating the exploration of the current brand mantra [Stage A], offline footprint [Stage B], online footprint [Stage C], assess its consistency [Stage D] and overall current evaluation from the perspective of multiple-stakeholders. Multiple stakeholders could include constituents, the media, activists, supporters, party colleagues-officials and competitors. Phase two would be followed by phase three where the current introspective evaluation is compared/contrasted with the multi-stakeholder evaluations [Stage I] and this would highlight changes, refinements or continued development of the personal political brand identity. Phase three would also include an opportunity for politicians to conduct an environmental audit [Stage J] to evaluate factors such as changing political, economic, social and technological trends, monitor the wants and needs of constituents, assess competitor brands, relationships with the political party[s] and coalition partners. This in turn will support the management of the personal political brand and enable the politician to develop a desired identity. The three phased process should be repeated periodically to safeguard the political brand, assess coherency between current and desired positioning and continually develop and manage the identity for a constantly changing environment. 
Subsequently, this study also demonstrated how to conceptualise politician political brands with the strategy of personal branding. In addition, this study highlighted that personal political brands were structured around tangible dimensions such as physical appearance, style, online and offline communications and actions-activities, and also intangible dimensions such as lived experiences, life-stories, values, charisma and apparent authenticity and authority (Chen 2013; Gehl 2011; Green 2016). This study presents an updated Personal Political Brand Identity Appraisal Framework as a systematic diagnostic tool to assess current and desired identity from a multi-stakeholder perspective and a mechanism to develop and manage political brands periodically. This study concurs with earlier work in that personal branding can be used by celebrities, sports personalities, journalists, business leaders, entrepreneurs, students and also politicians as a strategy to project an authentic character, which is distinct from rivals and competitors (Chen 2013; Cortsen 2013; Gehl 2011; Lair et al. 2005; Ottovordemgentschenfelde 2017).

\section{Conclusion}

This study addressed explicit calls for further research to consider different typologies of political brands moving beyond the extensive research on political 'party' brands (Pich et al. 2018). More specifically, this study explored the creation and development of personal political brands and their envisaged identity from the perspective of two Icelandic Members of Parliament. This study demonstrated that the personal brand identities of Members of the Icelandic Parliament represented a clear brand mantra and created-managed via personal values and ideology and based on key issues that were personal to the individual. In addition, this study highlighted that personal brand identities were developed with offline and online touchpoints with the aim of communicating an aligned, clear and authentic political brand in the mind of Icelandic citizens. However, this study also revealed the challenges of managing an integrated personal brand identity given the problematic nature of the party-coalition political system. This study was made possible by bridging two constructs of commercial branding theory such as personal branding and brand identity transferred to the sub-discipline of political branding. In addition, the evaluation political brand identity was supported by building on the six-staged framework (Philbrick and Cleveland 2015) designed to examine the personal brands from an internal brand creator perspective. Nevertheless, this study puts forward an extended and renamed Personal Political Brand Identity Appraisal Framework to periodically audit the current and desired identities of politicians from a multi-stakeholder perspective, which will help develop and manage personal political brands.

Nevertheless, like all projects, there were limitations associated with this study and acknowledging the limitations will strengthen the ability to draw conclusions and support calls for further research in this area (Farmer et al. 2006; Jack and Raturi 2006; Scandura and Williams 2000). In this study for example, only two Members of Parliament served as participants. However, the elite interviews were longer in duration and this provided a greater opportunity to capture detailed stories of their life experiences and how their identities were created and developed over time (Beamer 2002; Rubin and Rubin 1995). In addition, each elite interview was complemented by reviewing additional public and private material such as manifestos, newspaper articles and other offline communication tools along with accessing 
their social media platforms and online activity. Reviewing multiple materials and published work is consistent with a qualitative case-study approach as the aim is to build an extensive picture of respondents' background, their feelings and experiences to address the research objectives (Schutt 2004; Warren and Karner 2005). It can also be helpful for new areas of study (Davies and Chun 2002; Yin 2009). In addition, each Member of Parliament represented a single case as case studies are not only restricted to organisations, campaigns or locations but also individuals (Lincoln and Guba 1985; Welch et al. 2011; Yin 2018). Further, interpretivist research is grounded in the ability to capture new discoveries and enrich understanding of the phenomenon rather than verify predetermined hypotheses and makes generalizable claims (Gummesson 2005; Riege 2003). Therefore, this study does not make claims of generalisability rather the elite interviews offered the opportunity to reveal deep insight into the phenomenon of personal political brand identities. Future research should build on this study and include a larger sample size across different political parties and across international contexts to compare the intentional identities, which will generate an even greater understanding of personal political brands.

Subsequently, this study contributes to the development of theory and practice. For example, this study contributes to theory by addressing the explicit calls for further research on political brands from an internal perspective (Harris and Lock 2010; Needham and Smith 2015; Nielsen 2015; Nielsen 2016; O'Cass and Voola 2011; Scammell 2015). Indeed, these revealing firsthand accounts into how internal brand identity of personal political brands is created, developed and managed. This study also extends an under-developed area of political branding by conceptualising politicians as personal political brands (Needham and Smith 2015; O'Cass and Voola 2011; Scammell 2015; Speed et al. 2015). In addition, this study makes a second contribution to theory. This research extends the six-stages of personal branding (Philbrick and Cleveland 2015) to the political environment and puts forward the Personal Political Brand Identity Appraisal Framework; a systematic three-phased agenda to evaluate current and desired identity from a multi-stakeholder perspective. Practitioners can utilise this research as a guide of how to audit the identities of their own personal political brands and improve their desired positions based on tangible and intangible elements. The Personal Political Brand Identity Appraisal Framework will provide practitioners a mechanism to evaluate their identity, assess consistency and investigate alignment with their political party brand.

- Future studies should utilise the Personal Political Brand Identity Appraisal Framework to assess the model's applicability, systematic qualities and workability to different settings and contexts from a multi-stakeholder standpoint.

- Future research should investigate personal political brands and their relationship with party political brands and potentially extend the Personal Political Brand Identity Appraisal Framework to include a phase to evaluate the identity of party political brands.

- Finally, future studies could operationalise the Personal Political Brand Identity Appraisal Framework and measure the identities of personal political brands to develop a scale to quantify the strength of current and desired identity. 


\section{References}

Aaker, D. (1996). Building Strong Brands, London: Simon and Schuster UK Ltd.

Aaker, D. and Joachimsthaler, E. (2002), Brand Leadership, London: Simon \& Schuster UK Ltd.

Alston, M. and Bowles, W. (2007), Research for Social Workers: An Introduction to Methods, London: Routledge.

Alsem, K. J. and Kostelijk, E. (2008). Identity Based Marketing: A New Balanced Marketing Paradigm. European Journal of Marketing, Vol.42 (9/10), 907-914.

Althingi (2018a), Members of Parliament; Pórunn Egilsdóttir. Available at: https://www.althingi.is/altext/cv/en/?nfaerslunr=164 [Accessed 15 September 2018].

Althingi (2018b), Members of Parliament; Áslaug Arna Sigurbjörnsdóttir. Available at: https://www.althingi.is/altext/cv/en/?nfaerslunr=182 [Accessed 15 September 2018].

Althingi (2018c) Tillaga um pingsályktunartillögu um mótun eigendastenfu ríkisins með sérstöku tilliti til bújarða. Available at:

https://www.althingi.is/altext/149/s/0020.html?fbclid=IwAR3bLqhxaNmbqNPa0FX9Td7naPmGEk7JvKK5ok6VtP1-UIkCnBb1kmesgo [Accessed 15.October 2018].

Aqeel, Z. Hanif, M. I. and Malik, M.S. (2017). Impact of co-branding and brand personality on brand equity: A study of telecom sector in Pakistan. Journal of Business and Retail Management Research, Vol.12 (1), 86-93.

Baines, P. and Harris, P. (2011). Marketing in the 2010 British General Election: perspectives, prospect, and practice. Journal of Marketing Management, Vol. 27 (7/8), 647-655.

Bale, T. (2008). A Bit Less Bunny-Hugging and a Bit More Bunny-Boiling? Qualifying Conservative Party Change under David Cameron. British Politics, Vol. 3 (3), 270-299.

Baumgarth, C. (2018). Brand management and the world of the arts: collaboration, cooperation, co-creation, and Inspiration. Journal of Product and Brand Management, Vol.27 (3), 237-248.

Baxter, P., \& Jack, S. (2008). Qualitative Case Study Methodology: Study Design and Implementation for Novice Researchers. The Qualitative Report, Vol. 13(4), 544-559.

Beamer, G. (2002). Elite Interviews and State Politics Research. State Politics \& Policy Quarterly, Vol. 2 (1), 86-96.

Bergqvist, C. (1999). Equal Democracies? Gender and Politics in the Nordic Countries. Nordic Council of Ministers. ISBN 978-82-00-12799-4.

Billard, T. J. (2018). Citizen typography and political brands in the 2016 US presidential election campaign Marketing Theory, Vol.18 (3), 421-431.

Bird, S. Wiles, J. L. Okalik, L. Kilabuk, J. and Egeland, G.M. (2009). Methodological consideration of storytelling in qualitative research involving Indigenous Peoples'. Global Health Promotion, Vol. 16 (4), 16-26. 
Bosch, J. Venter, E. Han, Y. and Boshoff, C. (2006). The Impact of brand identity on the perceived brand image of a merged higher education institution: Part one. Management Dynamics, Vol. 15 (2), 10-30.

Braun, V and Clarke, V. (2006). Using thematic analysis in psychology. Qualitative Research in Psychology, Vol. 3(2), 77-101

Bronn, P.S., Engell, A. and Martinsen, H. (2006). A Reflective Approach to Uncovering Actual Identity. European Journal of Marketing, Vol. 40 (7/8), 886-901.

Brooks, A. K. and Anumuda, C. (2016). Identity development in personal branding instruction, Adult Learning, Vol. 27 (1), 23-29.

Busby, R. and Cronshaw, S. (2015). Political Branding: The Tea Party and its use of participation branding. Journal of Political Marketing, 10.1080/15377857.2014.990850.

Butler-Kisber, L. (2010). Qualitative Inquiry: Thematic, Narrative and Arts-Informed Perspectives. London: Sage Publications Ltd.

Chen, C. P. (2013). Exploring personal branding on YouTube. Journal of Internet Commerce, Vol. 12 (4), 332-347.

Cortsen, K. (2013). Annika Sorenstam - a hybrid personal sports brands. Sports, Business and Management: An International Journal, Vol. 3 (1) 37-62.

Cwalina, W. And Falkowski, A. (2014). Political branding: political candidates positioning based on inter-object associative affinity index, Journal of Political Marketing, DOI:10.1080/15377857.2014.990842

Dahlen, M. Lange, F. and Smith, T. (2010). Marketing Communications: A Brand Narrative Approach, West Sussex: John Wiley and Sons Ltd.

Dann, S. Harris, P. Sullivan Mort, G. Fry, M. and Binney, W. (2007). Reigniting the fire: a contemporary research agenda for social, political and nonprofit marketing, Journal of Public Affairs, Vol. 7, pp. 291-304.

Davies, G. and Chun, R. (2002). Gaps between the Internal and External Perceptions of the Corporate Brand. Corporate Reputation Review, Vol. 5 (2/3), 144-158.

Davies, G. and Mian, T. (2010). The reputation of the party leader and the party being led. European Journal of Marketing, Vol. 44 (3-4), 331-350.

De Chernatony, L. (2007). From Brand Vision to Brand Evaluation. Oxford: Butterworth Heinemann.

De Landtsheer, C. and De Vries, P. (2015). Branding the Image of a Fox: The Psychological Profile of EU President Herman Van Rompuy. Journal of Political Marketing, DIO $10.1080 / 15377857.2014 .990836$

Easterby-Smith, M. Thorpe, R. and Jackson, P. (2015). Management and Business Research. London: SAGE Publications Ltd. 
Farmer, T. Robinson, K. Elliott, S.J. and Eyles, J. (2006). Developing and Implementing a Triangulation Protocol for Qualitative Health Research, Qualitative Health Research, Vol. 16 (3), 377-394.

Foddy, W. (2001). Constructing Questions for Interviews and Questionnaires: Theory and Practice in Social Research. Cambridge UK: Cambridge University Press

French, A. and Smith, G. (2010). Measuring political brand equity: a consumer-oriented approach. European Journal of Marketing, Vol. 44 (3/4), 460-477.

Gallup (2018). Prentmiðlar Niðurstöður Júlí. Available at: https://www.gallup.is/nidurstodur/fjolmidlar/prentmidlar/ [Accessed 15.10.18].

Gehl, R. W. (2011). Ladders, samurai, and clue collars: Personal branding in Web 2.0. First Monday Journal, Vol.16 (9), 1-13.

Gillham, B. (2005). Research Interviewing: the range of techniques. Berkshire England: Open University Press.

Glaser, B. G. (2014), Memoing: A vital Grounded Theory Procedure. Mill Valley, CA: Sociology Press

Green, M. R. (2016) The impact of social networks in the development of a personal sports brand. Sports, Business and Management: An International Journal, Vol. 6 (3), 274-294.

Grimmer, M. and Grube, D. C. (2017), 'Political branding: A consumer perspective on Australian political parties' Journal of Party Politics, 1-14, DOI: $10.1177 / 1354068817710585$

Grube, D. C., \& Grimmer, M. (2017). Political branding: A consumer perspective on Australian political parties. Party Politics https://doi.org/10.1177/1354068817710585

Gummesson, E. (2005). Qualitative research in marketing: Role-map for a wilderness of complexity and unpredictability. European Journal of Marketing, Vol. 39 (3-4), 309-327.

Guzmán, F. Paswan, A.F and Van Steenburg, E. (2015). Self-Referencing and Political Candidate Brands: A Congruency Perspective. Journal of Political Marketing, Vol. 14 (12, 175-199, DOI: $\underline{10.1080 / 15377857.2014 .990837}$

Guzman, F. and Sierra, V. (2009). A political candidate's brand image scale: Are political candidates brands? Journal of Brand Management, Vol .17 (3), 207-217.

Gylling, C. and Lindberg-Repo, K. (2006). Investigating the links between a corporate brand and a customer brand. Journal of Brand Management, Vol. 13 (4/5), 257-267.

Harris, P., and Lock, A. (2010). Mind the gap: the rise of political marketing and a perspective on its future agenda. European Journal of Marketing, Vol. 44 (3/4), 297-307.

Harris, L. and Rae, A. (2011). Building a personal brand through social networking' Journal of Business Strategy, Vol. 32 (5), 14-21. 
Henley, J (2018). Iceland's New Leader: People don't trust our politicians. The Guardian [online], 9 February. Available at: https://www.theguardian.com/world/2018/feb/09/icelandsnew-leader-people-dont-trust-icelandic-politicians [Accessed 15.08.18].

Hofstede, A. Van Hoof, J. Walenberg, N. and De Jong, M. (2007), 'Projective techniques for brand image research'. Qualitative Market Research: An International Journal, 10 (3), 300309.

Hughes, A. and Dann, S. (2009). Political Marketing and Stakeholder Engagement. Journal of Marketing Theory, Vol. 9 (2), 243-256.

Jack, E. P. and Raturi, A. S. (2006). Lessons learned from methodological triangulation in management research. Management Research News, Vol. 29 (6), 345-357.

Jain, V. Chawla, M. Ganesh, B. E. Pich, C. (2018). Exploring and consolidating the brand personality elements of the political leader. Spanish Journal of Marketing, Vol, 22 (3), 295318, https://doi.org/10.1108/SJME-03-2018-0010

Johnson, K. (2014). The importance of personal branding in social media: education students to create and manage their personal brand. International Journal of Education and Social Sciences Vol. 4 (1), 1-8.

Joakim, N. (2006). Nordic and other European constitutional traditions. Leiden: Martinus Njihoff Publisers. P. 34. ISBN 978-978-90-04-15171-0.

Kapferer, J.N. (2008), The New Strategic Brand Management: creating and sustaining brand equity long term, London: Kogan Page Ltd.

Kornum, N. and Muhlbacher, H. (2013). Multi-stakeholder virtual dialogue: Introduction to the special issue. Journal of Business Research, Vol. 66 (1), 1460-1464.

Lair, D. J. Sullivan, K. and Cheney, G. (2005). Marketization and the Recasting of the Professional Self: The Rhetoric and Ethics of Personal Branding. Management Communication Quarterly, Vol. 18 (3) 307-343.

Lees, C, (2005). Political Marketing in Germany, In: Liliker, D and Lees-Marshment, J. (2005). Political Marketing: A Comparative Perspective. $2^{\text {nd }}$ Edition. Manchester. Manchester University Press.

Lees-Marshment, J. (2009). Political Marketing: Principles and Applications, Abingdon Oxon: Routledge.

Lees-Marshment, J. (2001). The product, sales and market-oriented party: How Labour learnt to market the product, not just the presentation. European Journal of Marketing, Vol. 35(9/10). 1074-1084.

Lillieker, D. G. (2003), Interviewing the Political Elite: Navigating a Potential Minefield. Politics, Vol 23 (3), 207-214.

Lincoln, Y. S. and Guba, E. G. (1985). Naturalistic inquiry. Newbury Park: CA: Sage

Lock, A. and Harris, P. (1996).Political Marketing - vive la difference!. European Journal of Marketing, Vol. 30 (10/11), 21-31. 
Magnúsdóttir, E (2017). Óvenjulega mikil endurnýjun. Morgunblaðið [online] 7 October. Available at: https://www.mbl.is/frettir/kosning/2017/10/07/ovenjulega_mikil_endurnyjun_2/ [Accessed 15.08.2018].

Marder, B. Marchant, C. Archer-Brown, C. Yau, A. and Colliander, J. (2018). Conspicuous political brand interactions on social network sites, European Journal of Marketing, Vol. 52 (3/4), 702-724, https://doi.org/10.1108/EJM-01-2017-0059

Marland, A. (2016.) Brand Command: Canadian Politics and Democracy in the Age of Message Control. Vancouver: UBC Press

Marland, A. and Flanagan, T. (2014). Brand New Party: Political Branding and the Conservative Party of Canada, Canadian. Journal of Political science, Vol. 46 (4), 951-972.

Marwick, A. E., \& Boyd, D. (2010). I tweet honestly, I tweet passionately: Twitter users, context collapse, and the imagined audience. New Media and Society, Vol. 13(1) 114-133

Milewicz, C.M. and Milewicz, M.C. (2014). The branding of candidates and parties: the U.S. news media and the legitimization of a new political term. Journal of Political Marketing, DOI:10.1080/15377857.2014.990836

Moufahim, M. Wells, V. and Canniford, R. (2018). The consumption, politics and transformation of community. Journal of Marketing Management, 34 (7-8), 557-568.

Nandan, S. (2005). An exploration of the brand identity-brand image linkage: A communications perspective, Journal of Brand Management, Vol. 12 (4), 264-278.

Needham, C., \& Smith, G. (2015). Introduction: Political Branding. Journal of Political Marketing, Vol. 14, 1-6.

Nielsen, S.W. (2016). Measuring Political Brands: An Art and a Science of Mapping the Mind, Journal of Political Marketing, Vol. 15 (1), 70-95.

Nielsen, S. W, (2015). On Political Brands: A Systematic Review of the Literature. Journal of Political Marketing, DOI: 10.1080/15377857.2014.959694, 1-29.

Nord, L.W. and Stromback, J. (2009). Marketing with a Feeling: The Brand New Party Junilistan on the Swedish European Parliamentary Elections 2004. Journal of Political Marketing, Vol. 8 (1), 35-45.

O'Cass, A. (2001). An investigation of the political marketing concept and political market orientation in Australian parties. European Journal of Marketing, Vol. 35(9/10), 1003-1025.

O'Cass, A., \& Voola, R., (2011). Explications of political market orientation and political brand orientation using the resource-based view of the political party. Journal of Marketing Management, Vol. 27 (5-6), 627-645.

Ormrod, R. P. (2011). Limitations and implications of product-orientated, sales-orientated and market-orientated political parties: evidence for public affairs. Journal of Public Affairs, Vol. 11(4), 395-405.

Ormrod, R. P, (2007). Political Market Orientation and Its Commercial Cousin, Journal of Political Marketing, Vol. 6 (2-3), 69-90. 
Ottovordemgentschenfelde, S. (2017). Organizational, professional, personal: An exploratory study of political journalists and their hybrid brand on Twitter. Journalism, Vol. 18 (1), 64-80

Panigyrakis, G. and Altinay, L. (2017). Political branding in turbulent times. The Service Industries Journal, 37 (9-10), 681-683

Peng, N. and Hackley, C. (2009). Are Voters, Consumers? A qualitative exploration of the voter-consumer analogy in political marketing. Qualitative Market Research: An International Journal, Vol. 12 (2), 171-186.

Peters, T. (1997). The Brand Called You. Fast Company, 10: 83.

Philbrick, J. L., \& Cleveland, A. D. (2015). Personal Branding: Building Your Pathway to Professional Services. Medical Reference Services Quarterly, Vol. 34 (2), 181-189.

Phipps, M. Brace-Govan, J. and Jevons, C. (2010). The duality of political brand equity. European Journal of Marketing, Vol. 44 (3/4), 496-514.

Pich C., Armannsdottir G., Spry L. (2018). An exploratory case study focusing on the creation, orientation and development of a new political brand; The case of the UK Jury Team. Journal of Politics and Policy, DOI: 10.1111/polp.12243

Pich, C. and Dean, D. (2015). Political Branding: Sense of Identity or Identity Crisis? An investigation of the transfer potential of the brand identity prism and the UK Conservative Party. Journal of Marketing Management, DOI: 10.1080/0267257X.2015.1018307

Rampersad, H.K. (2008). A New Blueprint for Powerful and Authentic Personal Branding. Performance Improvement, Vol. 47 (6), 34-37.

Resnick, S. M. Cheng, R. Simpson, M. and Lourenco, F. (2016). Marketing in SMEs: a 4Ps Self-Branding Model. International Journal of Entrepreneurial Behaviour and Research, Vol. 22 (1), 155-174.

Riege, A. M. (2003). Validity and reliability in case study research: a literature review with "hands-on" applications for each research phase. Qualitative Market Research: An International Journal, Vol. 6 (2), 75-86.

Ronzoni, G. Torres, E. and Kang, J. (2018). Dual branding: a case study of Wyndham, Journal of Hospitality and Tourism Insights, Vol. 1 (3), 240-257,

Rubin, H.J. and Rubin, I.S. (1995). Qualitative Interviewing: The Art of Hearing Data, London: Sage Publications Ltd.

Saunders, M. Lewis, P. and Thornhill, A. (2012). Research Methods for Business Students. Essex: Pearson Professional Ltd.

Scammell, M. (2015). Politics and Image: The Conceptual Value of Branding, Journal of Political Marketing, Vol. 14 (1-2), 7-18.

Scandura, T. A. amd Williams, E. A. (2000). Research Methodology in Management: Current Practices, Trends and Implications for Future Research. The Academy of Marketing Journal, Vol. 43 (6), 1248-1264. 
Schofield, P. and Reeves, P. (2015). Does the factor theory of satisfaction explain political voting behaviour? European Journal of Marketing, Vol.49 (5/6), 968-992.

Schutt, R. K. (2004). Investigating the Social World: The Process and Practice of Research, London: Sage Publications Ltd.

Serazio, M. (2017). Branding politics: Emotion, authenticity, and the marketing culture of American political communication. Journal of Consumer Culture, Vol.17 (2), 225-241

Shepherd, I. D. H. (2005). From Cattle and Coke to Charlie: Meeting the Challenge of SelfMarketing and Personal Branding. Journal of Marketing Management, Vol. 21 (5-6), 589606.

Sigurbjörnsdóttir, Á, A. (2018a) Twitter page. Available at:

https://twitter.com/aslaugarna?ref_src=twsrc\%5Egoogle\%7Ctwcamp\%5Eserp\%7Ctwgr\%5Ea uthor [Accessed 15 September 2018].

Sigurbjörnsdóttir, Á, A. (2018a) Facebook page. Available at:

https://www.facebook.com/aslaugarna/ [Accessed 15 September 2018].

Sigurbjörnsdóttir, Á, A. (2018a) Instagram page. Available at:

https://www.instagram.com/aslaugarna/?hl=en [Accessed 15 September 2018].

Silverman, D. (2013). Doing Qualitative Research, A Practical Handbook, (4 $\left.{ }^{\text {th }} e d.\right)$ London: Sage.

Smith, G. (2009). Conceptualising and Testing Brand Personality in British Politics. Journal of Political Marketing, Vol. 8 (3), 209-232.

Smith, G. (2005). Positioning Political Parties: The 2005 UK General Election. Journal of Marketing Management, Vol. 21 (4), 1135-1149.

Smith, G. (2001). The 2001 General Election: Factors Influencing the Brand Image of Political Parties and their Leaders. Journal of Marketing Management, Vol. 17, 989-1006.

Smith, G. and French, A. (2009). The political brand: A consumer perspective. Marketing Theory, Vol. 9 (2), 209-226.

Smith, G. and Speed, R. (2011). Cultural branding and political marketing: An exploratory analysis. Journal of Marketing Management, Vol. 27 (13-14), 1304-1321.

Smith, G. and Spotswood, F. (2015), The brand equity of the Liberal Democrats in the 2010 General Election: a national and local perspective. Journal of Political Marketing, Vol. 12 (23), DOI: $10.1080 / 15377857.2013 .781478$.

Speed, R. Butler, P. and Collins, N. (2015). Human branding in political marketing: Applying contemporary branding thoughts to political parties and their leaders. Journal of Political Marketing, Vol. 12 (2-3), DOI: 10.1275/15333457.2013.781278.

Thompson-Whiteside, H. Turnbull, S. and Howe-Walsh, L. (2017). Developing an authentic personal brand using impression management behaviours: exploring female entrepreneurs' experiences. Qualitative Market Research: An International Journal, DOI: 10.1108/QMR-012017-0007. 
Ward, C., and Yates, D. (2013). Personal branding and e-professionalism. Journal of Service Science, Vol. 6(1), 101-104

Warren, C.A.B. and Karner, T.X. (2005). Discovering Qualitative Methods: Field Research, Interviews and Analysis. California: Roxbury Publishing Company.

Welch, C. Piekkari, R. Plakoyiannaki, E. and Paavilainen-Mantymaki, E. (2011). Theorising from case studies: Towards a pluralist future for international business research. Journal of International Business Studies, Vol. 42, 740-762.

Wolfram, N. (2017). "Iceland”. Parties and Elections in Europe, http://www.parties-andelections.eu/iceland.html

Yin, R.K. (2018). Case Study Research and Applications, Design and Methods, (6 ${ }^{\text {th }}$ ed.) Thousand Oaks, CA: Sage.

Yin, R. K, (2009). Case Study Research, (4 ${ }^{\text {th }}$ ed.) Thousand Oaks, CA: Sage.

Zikmund, W.G. (2003) Business Research Methods, USA: Thomson Learning South-Western. 


\section{Opening - Introduction}

- Research outline-objectives

- Outline confidentiality, informed consent - audio tape - contact details for participant

\section{Biographical Information}

- How long in politics?

- How/why did you get into politics?

- Political background?

- Party politics?

- Other roles/jobs?

- Current role?

\section{Icelandic Political Brand Identity}

- What does it mean to be a Member of Parliament?

- How does the political system in Iceland work?

- Day in the life of an Icelandic Member of Parliament?

- Core values? Heritage?

- Key issues of concern?

- Personality?

- Ideology?

- What makes you different from your political competitors?

- How do you communicate your identity?

- What does it mean to be an MP?

- How do you feel about party politics? Political parties?

- Political allies? Political rivals?

- Relationships?

- Target Market?

- Overall self-image

\section{Coalition Politics}

- How does it work?

- Positives/negatives?

- Party identity?

- Coalition identity?

- Personal identity-party-coalition?

\section{Policies}


- Key policies of interest? Why?

- Party policies?

- Coalition policies?

- Policy most proud of and least proud of?

- One thing you would change tomorrow?

\section{Personal Perceptions}

- Party politics or non-party politics

- Approachable? Engaging?

- Communication with voters-citizens?

- Your personal political 'brand' in three words?

- How do your constituents see you?

- Political heroes inside-outside Iceland

- If you were PM tomorrow, what would you do?

\section{Closure}

- Questions for me

- Summarise Findings

- Reinforce Ethical Procedures

- Contact Information 